\title{
Effect of chestnut tannins on the root-knot nematode Meloidogyne javanica
}

\author{
L. MAISTRELLO ${ }^{1}$, G. VACCARI $^{1}$, N. SASANELLI ${ }^{2}$ \\ ${ }^{1}$ Department of Agricultural and Food Sciences, University of Modena and Reggio Emilia, Area S. Lazzaro, \\ Pad. Besta, Via G. Amendola 2, 42100 Reggio Emilia, Italy. E-mail: lara.maistrello@unimore.it; \\ ${ }^{2}$ Institute for Plant Protection, CNR, Section of Nematology, Via G. Amendola 122/D, 70126 Bari, Italy, \\ E-mail:n.sasanelli@ba.ipp.cnr.it
}

\begin{abstract}
Summary
Among the natural products extracted from plants, tannins have been reported to possess antihelmintic properties especially for gastrointestinal nematodes in ruminants. Also, they are toxic to a wide range of fungi, bacteria and yeasts. Therefore, an in vitro and a glasshouse pot experiments were undertaken to evaluate the effect of chestnut tannins on the control of the root-knot nematode Meloidogyne javanica. In the in vitro experiment, different tannin concentrations in a geometric scale (from 0.32 to 20.48 $\mathrm{g} / \mathrm{l})$, were tested for their effect on hatching of the nematode, whereas in the pot experiment, 100, 250 and 450 $\mathrm{g} / \mathrm{m}^{2}$ of tannins in aqueous solutions, were used in pots at transplant or at transplant and two weeks later for their effect on nematode control. In both experiments treatments were compared to untreated and fenamiphos-treated controls. In vitro a nematostatic effect of tannins was observed, whereas in the pot experiment a significant reduction of eggs and juveniles/g root, total population density and reproduction rates of the nematode were recorded. The anatomical changes induced by $M$. javanica in tomato roots treated with tannins did not differ from those produced by this and other Meloidogyne species on various hosts reported earlier.
\end{abstract}

Keywords: Meloidogyne javanica; nematode control; chestnut tannins

\section{Introduction}

The recent European Legislations (Reg. CE 396/2005; 1095/2007; 33/2008, 299/2008 and 1107/2009) have deeply revised and restricted the use of pesticides on agricultural crops focusing the attention on environmental safety, human and animal health. Plant protection from phytoparasitic nematodes and soilborne pathogens should therefore rely on alternative control strategies that are both environmentally sound and economically sustainable.
During the last two decades, research on low environmental impact alternatives to chemicals has received a strong impulse. A wide range of options was considered, including agronomic strategies (green manures, amendments, crop rotations, biofumigations, mycorrhization, grafting, resistant cultivars) (Gamliel et al., 2000; Sasanelli et al., 2002; Nico et al., 2004; Castillo et al., 2006; Renčo et al., 2007; 2009), physical methods (soil solarization, steam, ozone treatments) (Sasanelli \& Greco, 2000; Tamietti \& Valentino, 2000; Tjamos et al., 2000; Ciccarese et al., 2008), the use of bio-pesticides such as biological control agents (mainly fungi and bacteria) (Vannacci \& Gullino, 2000; Sasanelli et al., 2008); and biocidal plants belonging to different botanical families and/or their derived products (Gommers, 1981; Grainge \& Ahmed, 1988; Sasanelli et al., 2007).

Focusing especially on plants, many products such as essences, essential oils and aqueous extracts, have been reported for their biocidal effect on fungi, weeds and bacteria (Kurita et al., 1981; Janssen et al., 1987; Müller-Riebau et al., 1995; Isman, 2000) as well as soil dwelling insects (McCaffrey et al., 1995; Elberson et al., 1996; Sharaby et al. 1997; Maistrello et al., 2001; 2003). Natural plant products could provide a potential alternative to synthetic chemicals also for the control of soilborne pathogens and parasites, such as phytoparasitic nematodes (Sasanelli, 1992; Sasanelli \& D’Addabbo, 1993; Oka et al., 2000; Rodríguez-Kábana \& Simmons, 2005).

Among the natural products extracted from plants, tannins have been reported in the literature to possess antihelmintic properties especially for gastrointestinal nematodes in ruminants and the role of condensed tannins in the antiparasitic activity seems to be strongly substantiated by results both in vivo and in vitro (Hukkeri et al., 1993; Lopez et al., 2005; Hoste et al., 2006). Tannins, with a high affinity to proteins and polysaccharides, are secondary plant polyphenols whose physical and chemical properties 
can change according to the plants, parts of the plants and the season in which they are produced (Waterman, 1999; Waghorn \& McNabb, 2003). Moreover, tannins protect several plants against herbivores (Feeny, 1976) and they are toxic to a wide range of fungi, bacteria and yeasts (Scalbert, 1991).

Very little information is available on the effect of tannins on free-living or phytoparasitic nematodes (Taylor \& $\mathrm{Mu}-$ rant, 1966; Saly, 1989; Hewlett et al., 1997), although the plant pests can cause severe damages to many agricultural crops (Seinhorst, 1965; 1979; Sasanelli, 1994).

The objective of the present work was to evaluate the effect of chestnut tannins on: i) the root-knot nematode Meloidogyne javanica (Treub) Chitw. both in vitro and in a pot experiment on tomato under controlled conditions and ii) the histopathological variations induced by the nematode attack.

\section{Material and Methods}

\section{In vitro experiment}

The tannins (SAVIOTAN ${ }^{\circledR}$, Nuova Rivart, Radicofani, Siena Province, Italy) were extracted by vapour from chestnut wood, without chemical solvents, in powder form after dehydration. Technical data and chemical composition of the used product are reported in Table 1. masses. Distilled water and an aqueous solution containing $5 \mu \mathrm{g} / \mathrm{ml}$ fenamiphos were used as controls (Greco \& Thomason, 1980). The dishes were arranged in a completely randomised design with four replicates per treatment and incubated in a growth cabinet at $20 \pm 2{ }^{\circ} \mathrm{C}$ (Ekanayake \& Di Vito, 1984).

Every week, emerged juveniles were counted and removed, and the hatching solutions renewed. Overall, the test lasted twelve weeks. After the first two weeks, the egg masses were removed from the tannin and fenamiphos solutions and the incubation continued for ten more weeks in distilled water only, according to an already described methodology (Sasanelli \& Di Vito, 1991; Sasanelli \& D'Addabbo, 1992).

At the end of the experiment, the egg masses were shaken for $3 \mathrm{~min}$ in a $1 \%$ sodium hypochlorite aqueous solution (Hussey \& Barker, 1973) and the unhatched eggs were counted. Numbers of juveniles emerging weekly were expressed as cumulative percent of the total initial population (hatched + unhatched eggs).

Data were subjected to analysis of variance (ANOVA), after arcsin square root transformation (Bliss' Tables), and means were compared by Least Significant Difference's Test. All statistical analysis were performed using the PlotIT program.

Table 1. Chemical composition and characteristics of Saviotan ${ }^{\circledR}$

\begin{tabular}{lccc}
\hline Characteristic & Unit measure & \% content & Analytic Method (UNI 4632) \\
\hline Density Baumè & ${ }^{\circ} \mathrm{Bè} / 15^{\circ} \mathrm{C}$ & 27 & NR LAB 006 \\
Tannin & $\% \mathrm{w} / \mathrm{w}$ & 75 & NR LAB 001-002 \\
Non tannin & $\% \mathrm{w} / \mathrm{w}$ & 18 & NR LAB 001-002 \\
Non soluble & $\% \mathrm{w} / \mathrm{w}$ & 1 & NR LAB 003 \\
Water & $\% \mathrm{w} / \mathrm{w}$ & 6 & NR LAB 001-002 \\
Dry content & $\% \mathrm{w} / \mathrm{w}$ & 94 & NR LAB 007 \\
Tannin/Non tannin rate & ---- & 4.1 & Calculation \\
pH (solutions 6.9 ${ }^{\circ}$ Bè) & --- & 3.5 & NR LAB 004 \\
$\begin{array}{l}\text { Setting materials } \\
(\text { solutions 6.9 }\end{array}{ }^{\circ} \mathbf{B e ̀ ) ~}$ & $\% \mathrm{v} / \mathrm{v}$ & 1 & NR LAB 008 \\
\hline
\end{tabular}

Different concentrations from 0.32 to $20.48 \mathrm{~g} / \mathrm{l}$, in a geometric series, were obtained by dissolving the largest rate of tannin in distilled water (Table 2).

An Italian population of M. javanica (Treub) Chitwood, from Torchiarolo (Brindisi Province), southern Italy, was reared for two months on tomato (Solanum lycopersicum L.) cv. Rutgers in a glasshouse at $25 \pm 2{ }^{\circ} \mathrm{C}$. Batches with fifty egg masses of $M$. javanica (averaging 10,000 eggs per batch) were prepared by collecting egg masses from infected tomato roots. The batches were placed on $2 \mathrm{~cm}$ diameter sieves $(215 \mu \mathrm{m}$ aperture $)$ in a $3.5 \mathrm{~cm}$ diameter Petri dish. Three $\mathrm{ml}$ of each test solution, sufficient to cover egg masses, were then added to four batches of egg

\section{Glasshouse experiment}

The same population of $M$. javanica used in the in vitro experiment was reared for two months on tomato cv. Rutgers in a glasshouse at $25 \pm 2{ }^{\circ} \mathrm{C}$. When large mature egg masses were formed, tomato roots were finely chopped and eggs and juveniles were quantified by processing 10 root samples of $5 \mathrm{~g}$ each with $1 \%$ aqueous solution of $\mathrm{NaOCl}$ (Hussey \& Barker, 1973). The roots were then thoroughly mixed with $3 \mathrm{~kg}$ of steam sterilised sandy soil $(\mathrm{pH} \mathrm{7.2;}$ sand $>99 \%$; silt $<1 \%$; clay $<1 \%$ and organic matter = $0.75 \%$ ) and used as inoculum. Appropriate amounts of this inoculum were thoroughly mixed with the steam sterilised sandy soil in each clay pot containing $1,000 \mathrm{ml}$ soil to give 


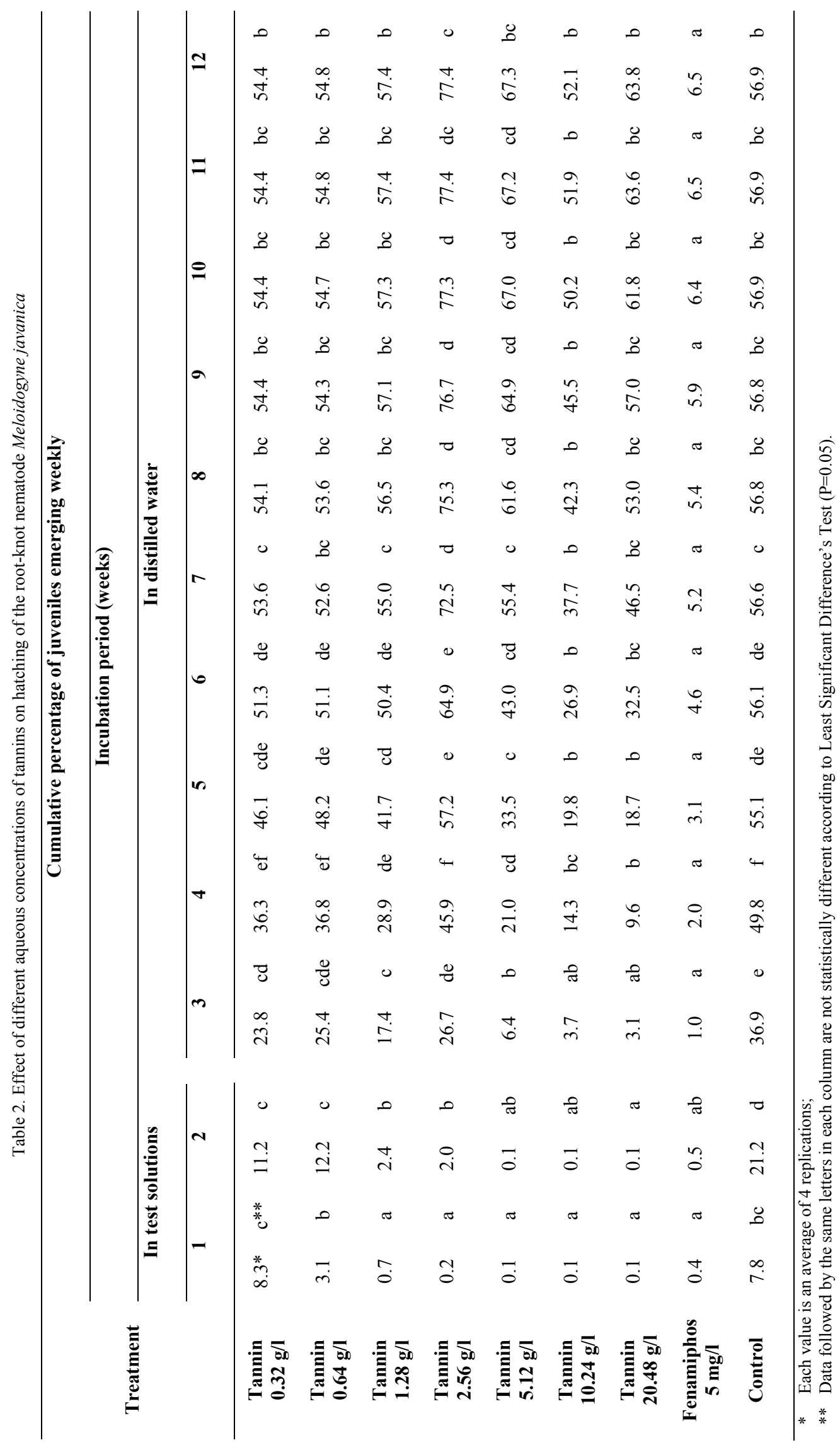


a nematode population density of 5 eggs and juveniles $/ \mathrm{cm}^{3}$ soil $(P i)$.

The pots were arranged on benches in a glasshouse at $25 \pm$ $2{ }^{\circ} \mathrm{C}$ in a randomized block design with 10 replicates for each treatment. Three tannin concentrations were considered: i) $100 \mathrm{~g} / \mathrm{m}^{2}$; ii) $250 \mathrm{~g} / \mathrm{m}^{2}$ and iii) $450 \mathrm{~g} / \mathrm{m}^{2}$, applied only at transplanting or at transplanting and two weeks later, for a total of six tannin treatments (Table 3). Nematode-infested untreated soil and fenamiphos treated soil were used as controls. In addition, an un-infested and untreated soil was considered. Fenamiphos was applied one day before transplanting at the rate of $62.5 \mathrm{l} / \mathrm{ha}$. Tannins were applied as aqueous solutions (400 ml/pot), calibrated on the water holding capacity of the soil.

After all treatments had been performed (for treatments 2, 4, 6 after the first session of treatments), in each pot a onemonth-old tomato seedling $\mathrm{cv}$. S. Marzano was transplanted.

During the experiment tomato plants were maintained in the glasshouse randomizing the position of the blocks and at the same time repositioning each plant within a block every week, to avoid a block position effect and at the same time the factor position of the plant within the block. Plants received all the necessary maintenance (irrigation, fertilization, etc.).

At the end of the experiment, two months later, plants were uprooted and height, fresh and dry top and root weight were recorded. Root gall index (GI) was estimated according to a $0-5$ scale, where $0=$ no galls; $1=1-2$ galls; $2=3-10$ galls; $3=11-30$ galls; $4=31-100$ galls and 5 $>100$ galls (Taylor \& Sasser, 1978).

Soil nematode population density in each pot was determined by processing $500 \mathrm{~cm}^{3}$ soil by the Coolen's method (Coolen, 1979). Numbers of $M$. javanica eggs and second stage juveniles in roots were assessed by cutting up each root system into small pieces and further comminuting them in a blender, containing $1 \%$ aqueous solution of $\mathrm{NaOCl}$ for $20 \mathrm{sec}$ (Marull \& Pinochet, 1991). The water suspension was then sieved through a $250 \mu \mathrm{m}$ pore sieve put over a $5 \mu \mathrm{m}$ pore sieve. Nematodes and root debris gathered on the $5 \mu \mathrm{m}$ pore sieve were further processed by centrifuging at 2,000 rpm for five $\mathrm{min}$ in $500 \mathrm{ml}$ of a magnesium sulphate solution of 1.16 specific gravity. Then eggs and juveniles in the water suspension were sieved through the $5 \mu \mathrm{m}$ pore sieve, sprayed with tap water to wash away the magnesium sulphate solution and collected in about $30-40 \mathrm{ml}$ water. Then they were counted and final nematode population density $(P f)$ in each pot was determined by summing nematodes recovered from soil and roots. The nematode reproduction factor $r$ was expressed as ratio between final and initial population density $(P f / P i)$ of $M$. javanica.

Data from the experiment were subjected to analysis of variance (ANOVA) and means compared by Least Significant Difference's Test. All statistical analysis were performed using the PlotIT program.

\section{Histopathology}

Galled roots from $M$. javanica infected tomato plants were used for histopathological studies. Roots were gently washed free of adhering soil and debris, and individual galls were selected together with root segments of un-infected plants. Galled and healthy root tissues were fixed in formaldehyde chromo-acetic solution for $48 \mathrm{~h}$, dehydrated in a tertiary butyl alcohol series $(40-70-85-90-100 \%)$ and embedded in $58{ }^{\circ} \mathrm{C}$ melting-point paraffin. Embedded tissues were sectioned with a rotary microtome. Sections 10 $-12 \mu \mathrm{m}$ thick were mounted on glass slides, stained with safranin and fast-green, mounted in dammar xylene and examined microscopically (Johansen, 1940).

\section{Results}

\section{In vitro experiment}

During the first two weeks, emergence of juveniles from egg masses was suppressed in all the aqueous solutions of tannin and fenamiphos (Table 2). All treatments with tannin in the range $1.28-20.48 \mathrm{~g} / 1$ did not significantly differ from fenamiphos. Only at the concentrations of 0.32 and $0.64 \mathrm{~g} / 1$ tannin the emergence of juveniles was significantly larger $(P=0.05)$ than that in fenamiphos, but less than that in distilled water (control) (Table 2).

When aqueous extracts of tannin and fenamiphos were removed and the incubation continued in distilled water, egg hatch of egg masses previously incubated in tannin solutions resumed, however, during the following three weeks for the egg masses which had been incubated in tannin at $5.12-20.48 \mathrm{~g} / \mathrm{l}$, hatching remained still lower $(18.7-33.5 \%)$ than the untreated control (Table 2), where more than $50 \%$ of the egg masses hatched. Emergence of juveniles in tannin at $10.24 \mathrm{~g} / \mathrm{l}$ was significantly lower than that in the control until the seventh week (Table 2). At the end of the incubation period (twelve weeks), the final cumulative hatch percentages in all tannin solutions did not differ from that in distilled water, except in aqueous solution at $2.56 \mathrm{~g} / \mathrm{l}$, in which it resulted significantly higher. Emergence of juveniles in the fenamiphos solution did not resume after transferring the egg masses in water and a final cumulative emergence of only $6.5 \%$ was recorded.

\section{Glasshouse experiment}

All treatments with tannin did not significantly $(P=0.01)$ increase tomato plants growth variables compared with the untreated control (Table 3). However, treatments with the highest doses of tannin (450 and $250 \mathrm{~g} / \mathrm{m}^{2}$ ) applied at transplant and again 2 weeks later, significantly reduced root gall index in comparison to inoculated and untreated control, similarly to the treatment with fenamiphos (Table 4).

The remaining treatments with aqueous solutions of tannin $\left(100\right.$ and $\left.250 \mathrm{~g} / \mathrm{m}^{2}\right)$ applied only at transplant, did not suppress nematode GI on the roots compared to untreated control, which resulted also significantly higher than that recorded in fenamiphos treated plants (Table 4). 


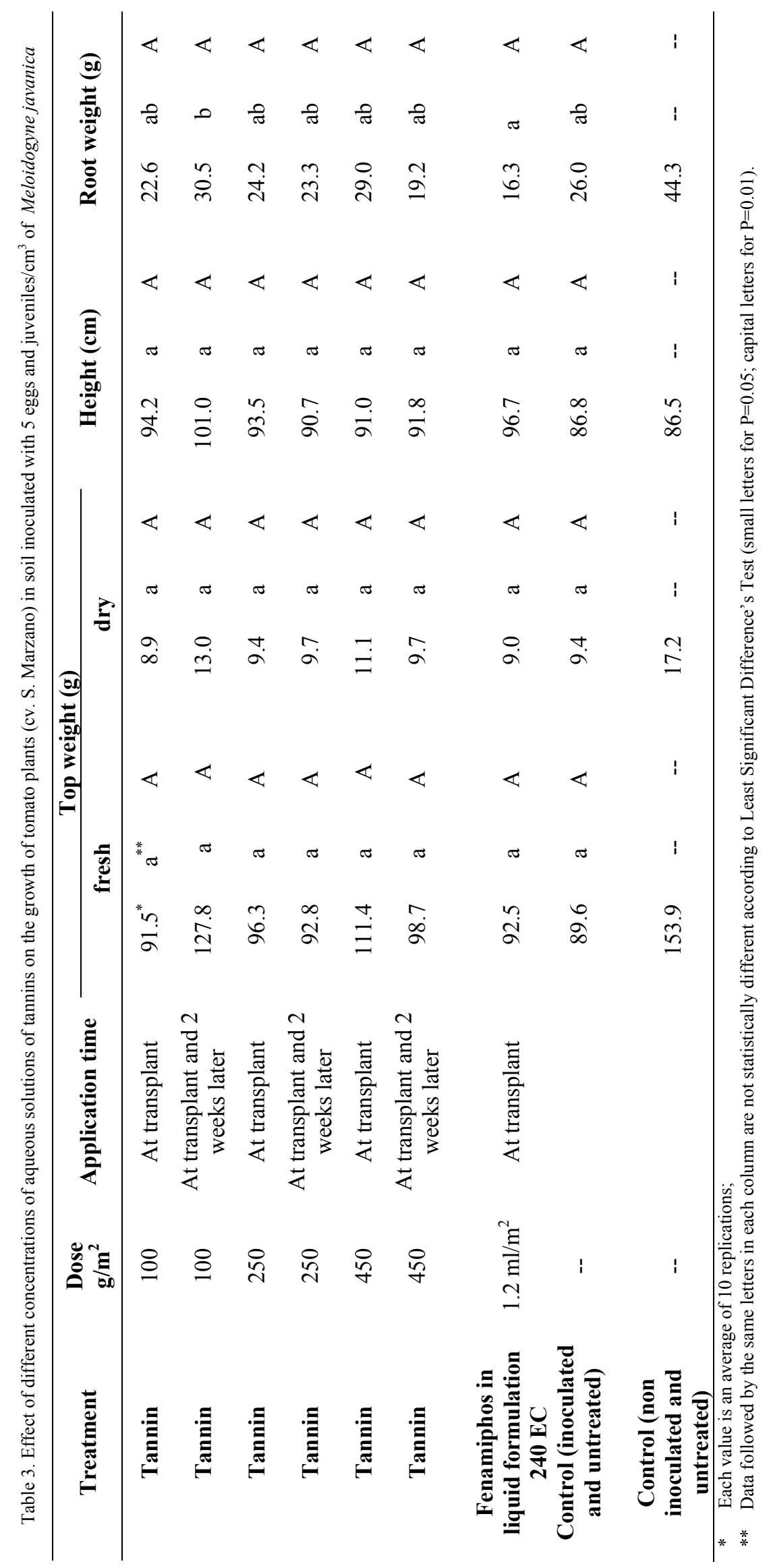




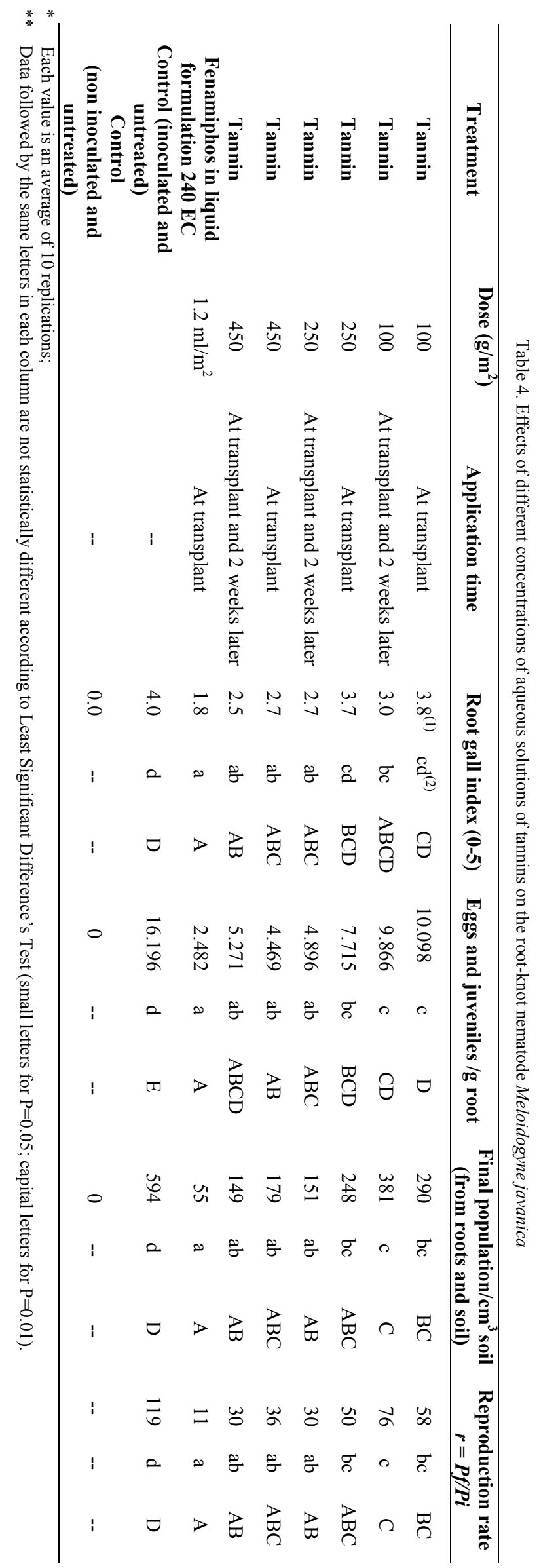


The number of eggs and juveniles of the nematode per gram of root in the inoculated untreated plants was significantly higher than that observed in all other treatments $(P$ $=0.01)$ (Table 4).

In plants treated with the highest doses of tannins, the number of eggs and juveniles per gram of root was not significantly different from that recorded in the fenamiphos treatment, whereas significant differences $(P=0.05)$ were observed in comparison to treatments with the lowest dose (100 $\mathrm{g} / \mathrm{m}^{2}$ ) applied at transplant and two weeks later (Table 4).

The treatments with medium and highest doses of tannins and fenamiphos significantly $(P=0.01)$ reduced $M$. javanica final population density $(P f)$ in the soil (eggs and juveniles $/ \mathrm{cm}^{3}$ soil) in comparison to untreated control. For this parameter, a significant difference was observed between fenamiphos and the lowest dose of tannin.

In the untreated control, nematode reproduction rate $(r=$ $P f / P i)$ was significantly larger than that of all other treatments $(P=0.01)$ (Table 4$)$. With the exception of the lowest dose $\left(100 \mathrm{~g} / \mathrm{m}^{2}\right)(P=0.01)$, tannin treatments, applied at transplant or at transplant and two weeks later, were not significantly different from fenamiphos (Table 4).

\section{Histopathology}

Root galls induced by $M$. javanica on tannin treated tomato roots varied in size and shape and occurred on both the main and lateral roots. Usually, galls contained more than one female. Observation of stained root sections revealed tissue hypertrophy and hyperplasia as well as disorganization and disruption of xylem elements and primary phloem cells. The nematode induced permanent feeding sites adjacent to vascular tissues consisting of groups of two to five large, multinucleate giant cells. Active multinucleated giant cells showed characteristic dense cytoplasm and numerous hypertrophied nuclei and nucleoli. Additionally, hyperplasia of tissues adjacent to the giant cells caused the root tissue expansion, leading to the formation of the observed root galling. The anatomical changes induced by $M$. javanica in tomato roots treated with tannins did not differ from those produced by this and other Meloidogyne species on various hosts reported earlier (Huang, 1985) (Fig. 1).

\section{Discussion and conclusions}

The in vitro experiment showed that tannin solutions greatly reduced nematode egg hatch. Between the third and the seventh week, the cumulative egg hatch percentage was gradually reduced as the applied concentrations increased. Probably a longer exposure to the tannin solutions (for more than 2 weeks) could have shown a nematicidal effect of these solutions. Hewlett et al. (1997) showed that tannic acid is an attractant for the root-knot nematodes $M$. arenaria (Neal) Chitw. and M. incognita (Kofoid \& White) Chitw., whereas it is repellent for Radophulus similis (Cobb) Thorne and without any effect on Heterodera glycines Ichinohe. Few attractants or repellents for $M$. javanica have been identified (Bird, 1959; 1960; Oteifa \& Elgindi, 1961). Application of attractants or repellents at
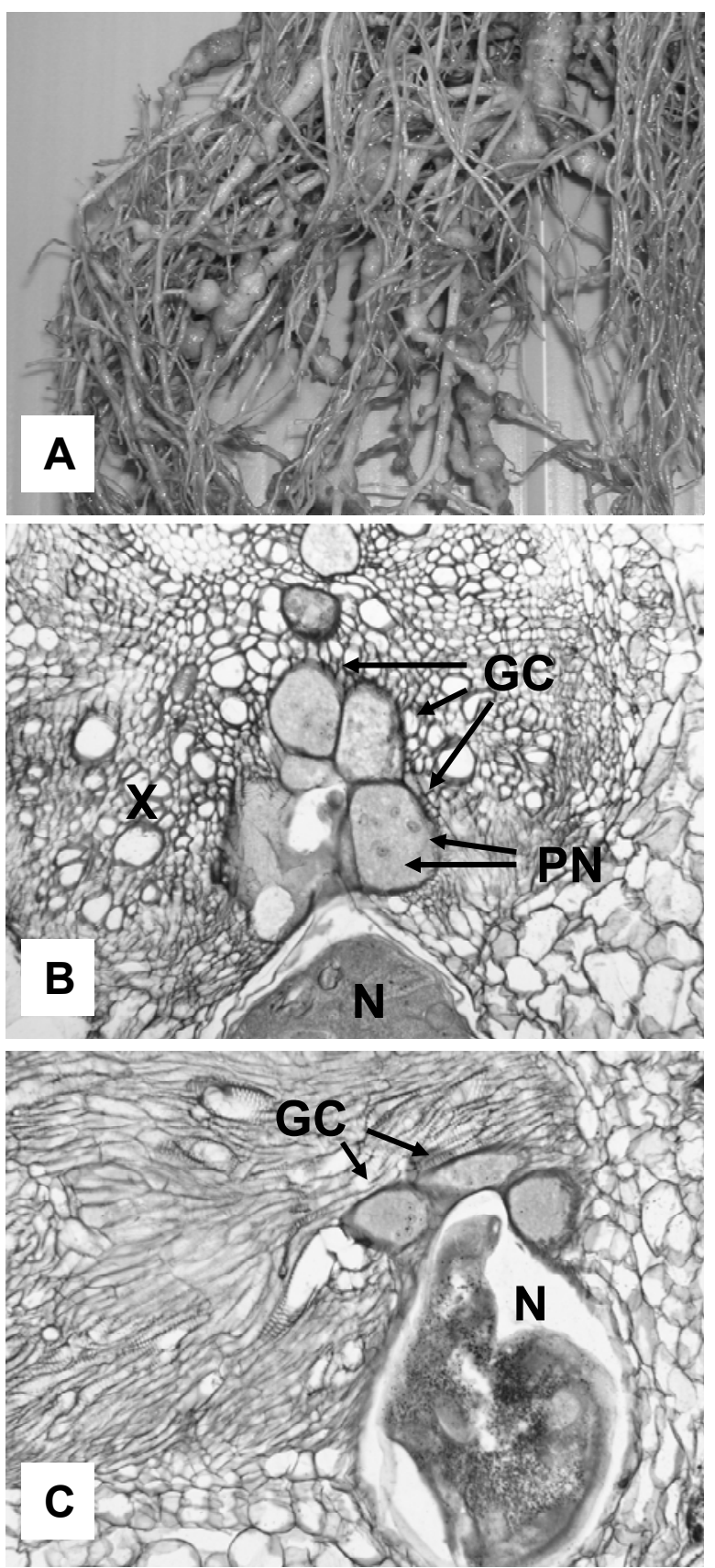

Fig. 1. Host-parasite relationship between Meloidogyne javanica and tomato plants treated with tannin solutions. Nematode infected tomato root (A). Transverve (B) and longitudinal sections (C) of root infested by M.javanica . $\mathrm{GC}=$ giant cells; $\mathrm{PN}=$ hypertrophic nucleous; $\mathrm{N}=$ nematode; and $\mathrm{X}=$ compressed xylem.

planting or before transplanting may serve to disorientate phytoparasitic nematodes causing them difficulties in locating the root systems and potentially reducing plant damage. Therefore, the observed nematostatic effect of aqueous solutions of tannins together with the combined characteristics of attractants might represent a possible control tactics for plant-parasitic nematodes, alternative to the repeated use of chemicals.

Results from the glasshouse experiment seem to confirm this hypothesis. In the pot experiment all doses of tannin 
$\left(100,250\right.$ and $\left.450 \mathrm{~g} / \mathrm{m}^{2}\right)$ reduced the number of eggs and juveniles/g root, the final population $/ \mathrm{cm}^{3}$ soil and the reproduction rate in comparison to infested untreated control. In particular, a significant reduction of the nematode gall index on the roots was obtained by the use of tannins at $250 \mathrm{~g} / \mathrm{m}^{2}$ applied two times, at transplant and two weeks later, demonstrating the protective and positive effect of repeated treatments. However, the lowest dose $\left(100 \mathrm{~g} / \mathrm{m}^{2}\right)$ of tannin was not sufficient to contain the initial nematode attack on the roots. Also in this case, there might be a close association of the level of this compound with nematode invasion. Tannin deposition occurred in parenchyma and endodermis cells of alfalfa roots invaded by Pratylenchus penetrans (Cobb) Filipjev \& SchuurmansStekhoven (Townsend et al., 1989; Zunke, 1990) and in banana roots infected by $R$. similis (Valette et al., 1997). The phenols content in roots is associated with the defence strategy of plants to nematode infection. Tannins are compounds that could be involved in the passive defence of the plant as chemical barriers to the invasion of the parasite in the roots and they might increase host resistance to nematode infection (Taylor \& Murant, 1966). It is necessary to consider that the nematicidal effect of various organic amendments and in particular of grape pomace against Meloidogyne spp. may be related also to the release of compounds such as polyphenols and tannins from the berry epidermis in which the tannin content can vary from 0.4 to $3 \%$ (D'Addabbo et al., 2000; Flanzy, 2000).

In conclusion, the use of tannins appears promising for the control of plant-parasitic nematodes in sustainable agriculture. However, further studies are suggested to investigate the effect of tannins in different types of soils and on different nematode species.

\section{Acknowledgements}

The present investigation was promoted and financed by AGROSTAR S.r.l. (Cavriago, Reggio Emilia), after foreseeing the applicative potential of tannins in plant protection, thanks also to the manifold intuitions of Dr. L. Marenchino (Research \& Development Division, Nuova Rivart S.r.1.). The authors thank Dr. N. Vovlas for his help in the histopathological study. All authors equally contributed in the experiments.

\section{References}

BIRD, A. F. (1959): The attractiveness of roots to the plantparasitic nematodes Meloidogyne javanica and M. hapla. Nematologica, 4: 322 - 335

BIRD, A. F. (1960): Additional notes on the attractiveness of roots to plant-parasitic nematodes. Nematologica, 5: 217 Castillo, P., Nico, A. I., Azcon-Aguilar, C., Del Rio Rincon, C., Calvet, C., Jimenez-Diaz, R. M. (2006): Protection of olive planting stocks against parasitism of root-knot nematodes by arbuscular mycorrhizal fungi. Plant Pathol., 55: 705 - 713. DOI: 10.1111/j.1365-3059. 2006.01400.x
Ciccarese, F., Paciolla, C., Sasanelli, N., Ciccarese, A., De LeOnardis, S., Sciacovelli, M. (2008): Can the ozone be used in the control of plant diseases? In Abstracts of $10^{\text {th }}$ Annual Congress FISV (Federazione Italiana Scienza della Vita), September 24 - 27, 2008. Riva del Garda, Italy, pp. 18

CoOlEN, W. A. (1979): Methods for the extraction of Meloidogyne spp. and other nematodes from roots and soil. In: LAMBERTI, F., TAYLOR, C. E. (Eds.) Root-knot nematodes (Meloidogyne species), Systematics, Biology and Control. London, UK: Academic Press, pp. 317 - 329

D’addabBo, T., SASAnelli, N., LAmberti, F., CARella, A. (2000): Control of root-knot nematodes by olive and grape pomace soil amendments. Acta Hortic., 532: 53 - 57 Elberson, L. R., BoreK, V., MCCAFFrey, J. P., Morra, M. J. (1996): Toxicity of rapeseed meal-amended soil to wireworms, Limonius californicus (Coleoptera: Elateridae). J. Agr. Entomol., 13: 323 - 330

EKANAYAKE, H. R. M. K., Di ViTO, M. (1984): Influence of root leachates and temperatures on egg hatch of Meloidogyne species. Nematol. Mediterr., 12: $119-127$

FEENY, P. (1976): Plant apparency and chemical defence. Recent Adv. Phytochem., 10: 1 - 40

FlANZY, C. (2000): Enología: Fundamentos científicos y tecnológicos. Madrid, España, Mundi-Prensa (Eds), 389 pp.

Gamliel, A., Austerweil, M., Kritzman, G. (2000): Non-chemical approach to soilborne pest managementorganic amendments. Crop Prot., 19, 847 - 853. DOI: 10.1016/S0261-2194(00)00112-5

GOMMERS, F. J. (1981): Biochemical interactions between nematodes and plants and their relevance to control. Helminthol. Abst. Series B, Plant Nematol., 50: 9-24

GRAINGE, M., AHMED, S. (1988): Handbook of Plants with Pest-Control Properties. $1^{\text {th }}$ Edition, New York, WILEY J. $\&$ SONS (Eds.). 470 pp.

GRECO, N., THOMASON, I. J. (1980): Effect of fenamiphos on Heterodera schachtii and Meloidogyne javanica. J. Nematol., 12: 91 - 96

Hewlett, T. E., Hewlett, E. M., Dickson, D. W. (1999): Response of Meloidogyne spp., Heterodera glycines and Radopholus similis to Tannic Acid. J. Nematol, 29: 737 741

Hoste, H., Jackson, F., Athanasiadou, S., Thamsborg, S. M., Hoskin, O. S. (2006): The effects of tannin-rich plants on parasitic nematodes in ruminants. Trends Parasitol., 22: 253 - 261. DOI: 10.1016/j.pt.2006.04.004

HUANG, C. S. (1985): Formation, anatomy and physiology of giant cells induced by root-knot nematodes. In: SASSER J. N. \& CARTER C. C. (Eds) An advanced treatise on Meloidogyne, Biology and Control, Vol. I. Raleigh, U.S.A.: North Carolina State University Graphics, pp. 155 $-164$

Hukkeri, V. I., Kalyani, G. A., Hatpaki, B. C., Marvi, V. F. (1993): In vitro antihelmintic activity of aqueous extracts of fruit rind of Punica granatum. Fitoterapia, 64: $69-70$

HuSSEY, R.S., BARKER, K.S. (1973): A comparison of 
methods of collecting inocula of Meloidogyne spp. including a new technique. Plant Dis. Reptr., 57: 1025 1028

ISMAN, M. B. (2000): Plant essential oils for pest and disease management. Crop Prot., 19: 603 - 608

JANSSEN, A. M., ShefFer, J. J. C., BAERHEIM SVENDSEN, A. (1987): Antimicrobial activity of essential oils: a 19761986 literature review: Aspects of the test methods. Planta Med., 53: 395 - 398

JohANSEN, D. A. (1940): Plant Microtechnique. McGrawHill Book Co., New York, NY (U.S.A.), 523 pp.

Kurita, N., MiYaJi, M., Kurane, R., TAKahara, Y. (1981): Antifungal activity of components of essential oils. Agr. Biol. Chem., 45: 945 - 952

Lopez, J., IbArRa, O. F., CANTO', G. J., VAsquez, C. G., TEJADA, Z. I., ShIMADA, A. (2005): In vitro effect of condensed tannins from tropical fodder crops against eggs and larvae of the nematode Haemonchus contortus. Int. J. Food, Agric. \& Environ., 3(2): 191 - 194

Maistrello, L., Henderson, G., Laine, R. A. (2001): Efficacy of vetiver oil and nootkatone as soil barriers against Formosan subterranean termite (Isoptera: Rhinotermitidae). J. Econ. Entomol., 94: 1532 - 1537

Maistrello, L., Henderson, G., Laine, R.A. (2003): Comparative effects of vetiver oil, nootkatone and disodium octaborate tetrahydrate on Coptotermes formosanus and its symbiotic fauna. Pest Manag. Sci., 59: 58 - 68 . DOI: $10.1002 /$ ps.601

Marull, J., Pinochet, J. (1991): Host suitability of Prunus rootstock to four Meloidogyne species and Pratylenchus vulnus in Spain. Nematropica, 21:185 - 195

McCaffrey, J. P., Williams, L., Borek, V., Brown P. D., MorrA, M. J. (1995): Toxicity of ionic thiocyanateamended soil to the wireworm Limonius californicus (Coleoptera, Elateridae). J. Econ. Entomol, 88: 793 - 797

Müller-Riebau, F., Berger, B., Yegen, O. (1995): Chemical composition and fungitoxic properties to phytopathogenic fungi of essential oils of selected aromatic plants growing wild in Turkey. J. Agr. Food Chem., 43(8): $2262-2266$

Nico, A. I., JimÉnez-DìAZ, R. M., CAstillo, P. (2004): Control of root-knot by composted agro-industrial wastes in potting mixtures. Crop Prot., 23: 581 - 587. DOI: 10.1016/j.cropro.2003.11.005

OKA, Y., NACAR, S., PUTIEVSKY, E., RAVID, U., YANIV, Z., SPIEGEL, Y. (2000): Nematicidal activity of essential oils and their components against the root-knot nematodes. Phytopathol., 90(7): $710-715$

OteIFA, B. A., Elgind, D. M. (1961): Physiological studies on host-parasite relationship on the root-knot nematode, Meloidogyne javanica. Plant Dis. Reptr., 45: 928 - 929

RenČO, M., D’adDabBo, T., SASAnelli, N., PAPAJOVA, I. (2007): The effect of five composts of different origin on the survival and reproduction of Globodera rostochiensis. Nematology, 9(4): 537 - 543. DOI: 10.1163/15685410778 1487260

RenČO, M., Sasanelli, N., Salamun, P. (2009): The effect of two compost soil amendments, based on municipal green and penicillin production wastes, on plant parasitic nematodes. Helminthologia, 46: 190 - 197. DOI: 10.2478/ s11687-009-0035-6

RodríGUEZ-KÁBANA, R., SIMMONS, L. (2005): Fungicidal, herbicidal, and nematicidal activities of essential oils in slow-release formulations. In: Abstracts XXVII Annual Meeting of ONTA, October 17 - 21, 2005. Viña del Mar, Chile, pp. 96

SALY, A. (1989): Seasonal dynamics of free-living nematodes in the rhizosphere of Fagus sylvatica in the Little Carpathians (Czechoslovakia). Helminthologia, 26: 73 - 83 SASANElli, N., Di ViTo, M. (1991): The effect of Tagetes spp. on the hatching of an Italian population of Globodera rostochiensis. Nematol. Mediterr., 19: 135 - 137

SASANELLI, N. (1992): Nematicidal activity of aqueous extracts from leaves of Ruta graveolens on Xiphinema index. Nematol. Mediterr., 20: 53 - 55

SASANElli, N., D'ADDABBO, T. (1992): The effect of Cineraria maritima, Ruta graveolens and Tagetes erecta extracts on the hatching of Heterodera schachtii. Nematol. Mediterr., 20: 49 - 51

SASANELLI, N., D’ADDABBO, T. (1993): Effect of Cineraria maritima, Ruta graveolens and Tagetes erecta leaf and root extracts on Italian populations of Meloidogyne species. Nematol. Mediterr., 21: $21-25$

SASANELLI, N. (1994): Tables of nematode-pathogenicity. Nematol. Mediterr., 22: 153 - 157

SASANELli, N., GRECO, N. (2000): Formulation of a model to relate nematode populations with exposure times to a range of temperatures. Acta Hortic., 532: 131 - 135

Sasanelli, N., D'adDabBo, T., Convrtini, G., Ferri, D. (2002): Soil Phytoparasitic Nematodes Suppression and Changes of Chemical Properties Determined by Waste Residues from Olive Oil Extraction. In: Proceedings of $12^{\text {th }}$ ISCO Conference, May 26 - 31, 2002. Beijing, China. Vol. III: $588-592$

Sasanelli, N., Attila, A., D’AdDabbo, T., Takacs, T. (2007): Nematicidal properties of leaf extracts of Ruta graveolens inoculated with arbuscular mycorrhizal fungi. Russ. J. Nematol., 15: $65-73$

Sasanelli N., Ciccarese F., Papajova I. (2008): Aphanocladium album by via sub-irrigation in the control of Pyrenochaeta lycopersici and Meloidogyne incognita on tomato in a plastic-house. Helminthologia, 45: $137-142$. DOI: 10.2478/s11687-008-0027-y

SCALBERT, A. (1991): Antimicrobial properties of tannins. Phytochem., 30: 3875 - 3883

SEINHORST, J. W. (1965): The relationship between nematode density and damage to plants. Nematologica, 11: 137 $-154$

SEINHORST, J. W. (1979): Nematodes and growth of plants: formulation of the nematode-plant system. In: LAMBERTI F. \& TAYLOR C.E. (Eds) Root-knot nematodes (Meloidogyne species) Systematics, Biology and Control. London, Academic Press, pp. 231 - 256

Sharaby, A., Ammar, N. (1997): Biological activity of extracts of Tephrosia nubica (Boiss) Baker against Spodoptera littoralis (Boisd.) and Agrotis ipsilon (Hufn.). 
Tropenlandwirt, 98: $143-150$

TAMiETti, G., VAlEntino, G. (2000): Effectiveness of soil solarization against soil borne plant pathogens and weeds in Piedmont (Northern Italy). Acta Hortic., 532: 151 - 156 TAYlor, C. E., Murant, A. F. (1966): Nematicidal activity of aqueous extracts from raspberry canes and roots. Nematologica, 12: 488 - 494

TAYlOR, A. L., SASSER, J. N. (1978): Biology, Identification and Control of Root-knot Nematodes (Meloidogyne spp.). Raleigh, North Carolina State University Graphic, N.C. (U.S.A.), $111 \mathrm{pp}$.

Tuamos, E. C., Polymnia, P. A., Tuamos, S. E. (2000): Implementation of soil solarization in Greece: Conclusions and suggestions. Crop Protection, 19: 843 - 846. DOI: 10.1016/S0261-2194(00)00132-0

Townsend, J. L., StobBs, L., CARTER, R. (1989): Ultrastructural pathology of cells affected by Pratylenchus penetrans in alfalfa roots. J. Nematol., 21: $530-539$
Valette, C., Nicole, M., Sarah, J. L., Boisseau, M., Boher, B., Fargette, M., Geiger, J. P. (1997): Ultrastructure and cytochemistry of interactions between banana and the nematode Radopholus similis. Fund. Appl. Nematol., 21: $65-77$

VAnNACCI, G., Gullino, M. L. (2000): Use of biological agents against soil borne pathogens: Results and limitations. Acta Hortic., 532: $79-88$

Waghorn, G. C., MCNABB, W. C. (2003): Consequences of plant phenolic compounds for productivity and health of ruminants. Proc. Nutr. Soc., 62: $383-392$

WATERMAN, P. G. (1999): The tannins - an overview. In: BROOKER J. D. (Eds) Tannins in livestock and human nutrition. Adelaide, Australian Centre for International Agricultural Research, Australia, pp. 10 - 13

ZUNKE, U. (1990): Observations on the invasion and endoparasitic behaviour of the root lesion nematode Pratylenchus penetrans. J. Nematol, 22: $309-320$ 